\title{
Coordination or conflict? The causes and consequences of institutional overlap in a disaggregated world order
}

\author{
B E N J A M I N F A U D E \\ London School of Economics and Political Science, Department of Government and Department of \\ International Relations, Houghton Street, London, WC2A 2 AE
}

Email: b.faude@lse.ac.uk

\begin{abstract}
J U L I A F U S S
WZB Berlin Social Science Center, Research Unit Global Governance, Reichpietschufer 50, 10785 Berlin, Germany
\end{abstract}

Email: julia.fuss@wzb.eu

\begin{abstract}
Institutional overlap emerges not only as an unintended by-product of purposive state action but also as its deliberate result. In two ways, this article expands existing research on the causes and consequences of institutional overlap. First, we establish that three different types of dissatisfaction may lead states to deliberately create institutional overlap: dissatisfaction with substantive norms and rules, dissatisfaction with decision-making rules and dissatisfaction with the institutional fit of an existing governance arrangement for a given cooperation problem. Each type of dissatisfaction triggers a distinct motivation for the creation of institutional overlap: to induce policy change, to increase influence on collective decisionmaking or to enhance governance effectiveness. Second, we demonstrate that whereas the motivation to induce policy change leads to interface conflicts, the motivations to increase influence on collective decision-making and to enhance governance effectiveness give rise to inter-institutional coordination. Three empirical case studies on global energy governance, the governance of global development banking and global environmental governance probe these analytical claims.
\end{abstract}

Keywords: coordination; fragmentation; global legal pluralism; institutional overlap; regime complexes

\section{Introduction}

On 26 January 2009, a group of states created the International Renewable Energy Agency (IRENA) because it was dissatisfied with the focus of the International Energy Agency (IEA) on fossil fuels as the main energy sources. 
The creation of IRENA was driven by the desire to circumvent political opposition within the IEA and to shape new norms that promote renewable energies (Van de Graaf 2013a). It led to interface conflicts between major industrialised and industrialising countries.

Furthermore, on 16 January 2016, a group of states led by China launched the Asian Infrastructure Investment Bank (AIIB) because it was dissatisfied with the reluctance of Western powers to redistribute influence within the World Bank (WB) (Ikenberry and Lim 2017). The creation of the AIIB was driven by China's desire to increase its institutional power in global development banking (Pratt 2017). It resulted in inter-institutional coordination with the WB.

Likewise, the creation of the Global Environment Facility (GEF) on the eve of the 1992 Rio Earth Summit induced inter-institutional coordination. The GEF was established on 28 October 1991 by states that were dissatisfied with the ability of both the United Nations (UN) and the WB to organise the funding of environmental projects in developing countries and countries with economies in transition. These states were motivated to boost the effectiveness of global environmental governance by creating an institutional framework that enables the redistribution of financial resources.

These three cases exemplify a larger, and growing, trend in global governance: the propensity of states to deliberately create institutional overlap (Alter and Raustiala 2018; Benvenisti and Downs 2007; Zürn and Faude 2013). Institutional overlap implies that separately established international institutions do not operate in isolation from each other, but influence each other's normative development and governance effectiveness (Dunoff 2012; Wiener et al. 2012). Thus, it reflects and facilitates change in the international legal order (Lang et al. 2013).

The Introduction to this Special Issue identifies the causes and consequences of institutional overlap as one of the three dominant questions that animate the literature on regime complexity and international legal multiplicity (cf. Hofmann 2011; Zelli and van Asselt 2013). Existing research suggests that deliberately created institutional overlap virtually always leads to conflicts between groups of actors that support diverging norms and rules (Benvenisti and Downs 2007; Morse and Keohane 2014). Thus, it cannot account for the emergence of inter-institutional coordination in two of the three cases introduced above. This shortcoming is due to the fact that existing research does not delve into the different motivations of actors to create institutional overlap (de Búrca 2016).

Against this backdrop, the present article develops three causal mechanisms that enable explaining why the creation of IRENA induced interface conflicts whereas the creation of the AIIB and the GEF resulted in interinstitutional coordination. More precisely, it makes two contributions. 
First, we establish that deliberately created institutional overlap can be caused by dissatisfaction with the substantive norms and/or rules of existing institutions, dissatisfaction with their decision-making rules or dissatisfaction with the institutional fit of an existing governance arrangement (which may consist of one or more than one international institution) for a given cooperation problem. ${ }^{1}$ Each of these three types of dissatisfaction with the institutional status quo triggers a distinct motivation to purposively create institutional overlap, namely to induce policy change, to increase influence on collective decision-making or to enhance governance effectiveness. ${ }^{2}$ Second, we elucidate why only dissatisfaction with substantive norms and rules leads to interface conflicts, whereas dissatisfaction with decisionmaking rules and institutional fit results in inter-institutional coordination. In short, the article argues that the consequences of deliberately created institutional overlap depend on its causes.

We therefore address interface conflicts as possible analytical end points of causal pathways that are triggered by specific types of dissatisfaction with the institutional status quo on the part of a group of states (cf. KreuderSonnen and Zürn, this issue). In so doing, we tackle one of the pivotal questions that motivate this Special Issue: Under which conditions does institutional overlap lead to interface conflicts and when does it induce inter-institutional coordination? More precisely, we enhance our understanding of 'when, why, and how overlaps [...] are seen, used, and abused by the actors of world politics' (Kreuder-Sonnen and Zürn, this issue).

In sum, we push forward research on international legal multiplicity by demonstrating how coherence among separately established international

\footnotetext{
${ }^{1}$ Institutional fit denotes the basic ability of an existing governance arrangement to achieve its designated governance objective (Young 2002). By implication, actors that are dissatisfied with institutional fit need not be able to assess the effectiveness of a certain governance arrangement in a fine-grained way. They only need to be able to assess whether an existing governance arrangement is basically able to effectively address a certain cooperation problem. States also need not be in full agreement as to how a given cooperation problem should be addressed. They only need to agree that a given cooperation problem is in need of an institutional response that is not yet (fully) provided.

${ }^{2}$ Our analytical categories are sufficiently broad and our theoretical logics sufficiently general to accommodate a wide variety of empirical cases. If, for example, a group creates a new institution to exert leadership or to reframe a problem, it does so because it seeks to induce policy change, increase influence on collective decision-making or enhance governance effectiveness. Moreover, every motivation imaginable presupposes some type of dissatisfaction with the institutional status quo. If, for example, states were perfectly satisfied with the existing governance arrangement, they would not be ready to accept the costs that come with exerting leadership or reframing a problem. And if a group of states is motivated by legitimacy concerns with or distributional effects of the existing governance arrangement, that motivation equally presupposes dissatisfaction with the substantive norms and rules, the decision-making rules or the institutional fit of an existing governance arrangement.
} 
legal orders is possible in the absence of constitutionalised structures (cf. Dunoff and Trachtman 2009; Krisch 2010). More precisely, we elucidate how the flexible adaptation that global legal pluralists highlight as a virtue of decentralised governance systems gives rise to coherent governance even if institutional overlap is deliberately created (Krisch et al., this issue). By implication, we call into doubt that the coexistence of partially overlapping normative orders is inherently destabilising the international legal system, as some global constitutionalists suggest (Dunoff and Trachtman 2009; Wiener et al. 2012).

The article is structured as follows: First, we introduce our central concepts. Second, we develop three causal mechanisms to account for the emergence of interface conflicts and inter-institutional coordination. Third, we demonstrate how interface conflicts have emerged between the proponents of the IEA and those of IRENA, and how inter-institutional coordination was realised between the WB and the AIIB, and between the GEF, other international environmental institutions and the WB.

\section{Introducing our central concepts: Institutional overlap, interface conflicts, inter-institutional coordination}

We speak of institutional overlap if the mandates of two or more separately established international institutions intersect on a de facto basis (Hofmann 2011). In areas of institutional overlap, two or more international institutions seek to govern the behaviour of actors by prescribing behavioural roles, constraining activity and shaping expectations (Keohane 1988: 383). More often than not, the governance efforts of overlapping international institutions diverge from each other. As a result, behavioural roles are not prescribed unequivocally, activities are not constrained clearly and expectations are not shaped definitively. Rather, institutional overlap gives rise to competing authority claims and, thus, to contestations among multiple centres of international authority in the absence of a formal hierarchy (Alter and Raustiala 2018:9). Thus, institutional overlap is widely perceived to have a destabilising effect on global governance (ILC 2006).

In our three cases, actors have deliberately created institutional overlap. As the Introduction to this Special Issue explains, such overlap is particularly prone to give rise to interface conflicts, defined as positional differences between actors over the prevalence of norms and/or rules enshrined in separately established but functionally overlapping international institutions (Kreuder-Sonnen and Zürn, this issue). Put differently, interface conflicts imply that actors hold conflicting positions on the scope and applicability of norms and/or rules enshrined in overlapping international institutions. 
They are created and become observable through contestations by actors in practices or speech acts (cf. Kreuder-Sonnen and Zürn, this issue).

However, institutional overlap may also give rise to inter-institutional coordination (Gehring and Faude 2013). We define inter-institutional coordination as the alignment of the governance activities of overlapping institutions in ways that give rise to coherent governance. Coordination is instantiated by procedural norms that effectively govern the relations among overlapping international institutions in ways that produce coherent governance (Gehring and Faude 2014; Krisch 2010: Ch 7).

Inter-institutional coordination presupposes the agreement of relevant actors. It therefore implies the absence or resolution of interface conflicts and competing claims to authority. That is, if inter-institutional coordination is realised, actors do not voice conflicting positions on the scope and applicability of norms and/or rules enshrined in overlapping international institutions. Rather, they recognise the distinct contributions all overlapping institutions make to global governance. Reaching inter-institutional coordination can be a highly political process, especially if it connects international institutions from different issue-areas, for example international trade institutions and international environmental institutions. Since international institutions from different issue-areas embody diverging societal rationalities, coordinating them is inherently political in nature (Koskenniemi 2012). International institutions from only one issue-area, by contrast, express the same societal rationality, e.g. promoting international trade or protecting the climate. Coordinating them is therefore less of a political and more of a technical exercise (Dunoff 2012).

\section{Connecting the causes and consequences of institutional overlap: Three causal mechanisms}

To explain why the creation of IRENA led to interface conflicts, whereas the creation of the AIIB and the GEF resulted in inter-institutional coordination, we develop three causal mechanisms. A causal mechanism is an analytical construct which enables the development of 'causal generalizations about recurring processes' (Mayntz 2009). It consists of a set of logically connected statements that specifies a distinct causal chain. Thus, causal mechanisms provide plausible accounts of how a given cause is connected to an observed effect (Schelling 1998).

Each of the three mechanisms developed below connects a specific type of dissatisfaction with a given institutional status quo to a specific motivation for the creation of institutional overlap and that motivation to a specific outcome. The object of dissatisfaction varies across the three mechanisms. 
Actors may be dissatisfied with substantive norms and rules, with decisionmaking rules or with the institutional fit of an existing governance arrangement to its social environment. ${ }^{3}$

Substantive norms and rules seek to govern the behaviour of state- and non-state actors. Decision-making rules, by contrast, govern how collectively binding decisions are made within international institutions. And institutional fit denotes the basic ability of an existing governance arrangement to achieve its designated governance objective such as international financial stability or the protection of human rights (cf. Young 2002). ${ }^{4}$

The motivations of states to create institutional overlap vary accordingly: if dissatisfied with substantive norms and/or rules, states become motivated to change the norms and/or rules that govern the behaviour of actors and, thus, the direction in which a given issue-area is governed (Helfer 2009); if dissatisfied with decision-making rules, they seek to increase influence on collective decision-making (Pratt 2017); if dissatisfied with institutional fit, they gain the motivation to increase governance effectiveness (Dunoff 2012; Young 2002). These different motivations, in turn, yield varying consequences for global governance.

Our causal mechanisms presuppose that states establish international institutions to realise their common interests and design them in ways that enable the realisation of joint gains (Koremenos et al. 2001). At the same time, we assume that every state cares about the distribution of cooperation gains and seeks to capture as many cooperation gains as possible (Krasner 1991). Moreover, it is conceivable that the interests of states evolve over time in reaction to exogenous change. Depending on the type of cooperation problem to be solved, this logic of action leads states to include institutional agents, such as secretariats or court-like bodies, in the institutional design. We expect such agents to act in accordance with states' preferences and the mandate of the institution.

\section{How dissatisfaction with substantive rules leads to interface conflicts}

Dissatisfied states have several options for seeking policy change with an existing international institution: they can voice dissent, threaten to cease implementing substantive norms or actually stop implementing them. If none of these actions yields change in substantive norms, there is still the option to create an overlapping institution.

\footnotetext{
${ }^{3}$ Dissatisfaction with institutional fit is particularly likely to arise as a result of exogenous change.

${ }^{4}$ For Young, institutional fit denotes the '(mis)match between properties of biogeophysical systems and attributes of institutions' (Young 2002: xiv). For us, institutional fit denotes the (mis) match between the institutional design of a governance arrangement and its social environment.
} 
We posit that interface conflicts between defenders and challengers of the institutional status quo are likely to emerge if institutional overlap is created to induce international policy change. If states that are dissatisfied with substantive norms resort to inter-institutional means to induce policy change, those that are satisfied with the institutional status quo were by implication successful in defending it. Thus, challengers and defenders inevitably hold positional differences on the prevalence of overlapping norms.

In order to identify this causal mechanism empirically, we need to observe a) utterances of states which indicate that they are dissatisfied with the substantive norms and/or rules of a given international institution, b) actions of those states that result in institutional overlap, c) justifications of those actions with the intention to change the prevalent substantive norms and/or rules, and d) conflicting positions between the defenders of the incumbent institution(s) and its challengers on the scope and applicability of norms and/or rules enshrined in the overlapping institutions. The mechanism is disconfirmed if dissatisfaction with substantive norms and/or rules leads to institutional overlap, but coordination is observable among the overlapping institutions instead of interface conflicts among its proponents.

\section{How dissatisfaction with decision-making rules leads to inter- institutional coordination}

If a group of states is dissatisfied with its influence on collective decisionmaking within an international institution, it may seek change in decisionmaking rules. For various reasons, however, such an effort may fail. Most importantly, redistributing influence within an existing institution is a zerosum game which is notoriously difficult to solve. Thus, states seeking to increase influence on collective decision-making are incentivised to create institutional overlap (Pratt 2017).

We posit that interface conflicts are unlikely to emerge if institutional overlap is created to increase influence on collective decision-making. Since defenders and challengers of the institutional status quo do not hold diverging positions with regard to substantive norms or rules, we expect the substantive norms institutionalised in the newly created institution to resemble those prevalent in the incumbent institution(s). By implication, the potential for interface conflicts is low. The emergence of interinstitutional coordination, by contrast, is more likely. It may be established if both groups share an interest in reaping the additional cooperation gains that can be generated by inter-institutional coordination compared to a situation of behavioural uncertainty created by competing claims to authority. 
In order to identify this causal mechanism empirically, we need to observe a) utterances of states which indicate their dissatisfaction with the decisionmaking rules of a given governance arrangement, b) actions of those states that result in institutional overlap, c) justifications of those actions with the intention to increase influence on collective decision-making, and d) the emergence of inter-institutional coordination which is visible in formal or informal institutional arrangements and in utterances of actors indicating their recognition of the distinct scopes of authority of all overlapping institutions. The mechanism is disconfirmed if dissatisfaction with decision-making rules leads to institutional overlap, but interface conflicts between the proponents of the overlapping institutions are observable instead of inter-institutional coordination.

\section{How dissatisfaction with institutional fit leads to inter-institutional coordination}

If a group of states is dissatisfied with the institutional fit of an existing governance arrangement, that is, if certain states are dissatisfied with its basic ability to solve the underlying cooperation problem, they may become motivated to create a new institution in order to enhance governance effectiveness (cf. Zelli and van Asselt 2013: 8). Most importantly, institutional fit is deficient if not all governance functions that are required to effectively address a given cooperation problem are provided by the existing institution(s). If this is the case, deficient institutional fit results from a 'governance gap' (Clarke 2019). It may be closed by expanding the mandate of an already existing institution. However, because any international institution includes a plethora of veto players, this is a cumbersome process which may easily fail. Actors may therefore decide to create a new institution that supplies the required governance function."

Enhancing governance effectiveness through increasing institutional fit requires synergistic co-governance. Thus, when states create a new institution in order to close a 'governance gap', they will carefully design that institution in a way that it complements those already existing (cf. Young 2002). By implication, actors will strive to avoid interface conflicts (Dunoff 2012).

In order to identify this causal mechanism empirically, we need to observe a) utterances of states which indicate their dissatisfaction with the institutional fit of an existing governance arrangement, b) actions of those states that result in institutional overlap, c) justifications of those actions with the intention to increase governance effectiveness, and d) the emergence

5 This causal mechanism therefore does not apply to 'regime-shifting' (Helfer 2009). 
of inter-institutional coordination (see above). This mechanism is disconfirmed if dissatisfaction with institutional fit leads to institutional overlap, but interface conflicts between different groups of actors are observable instead of inter-institutional coordination.

For analytical purposes, each of our causal mechanisms isolates one type of dissatisfaction with the institutional status quo as a trigger for the deliberate creation of institutional overlap. Empirically, it is nonetheless possible that states have more than one reason to be dissatisfied with a given institutional status quo. We posit, however, that if this is the case, it will nevertheless be possible to identify one dominant type of dissatisfaction. If so, the motivations of states that deliberately create institutional overlap converge around their specific types of dissatisfaction with the institutional status quo. This does, however, not imply that their preferences are completely homogenous. Rather, additional motivations (beyond those triggered by the specific type of dissatisfaction) are likely to diverge among those states.

\section{Coordination or conflict? Evidence from three empirical cases}

In the remainder of this article, we subject our causal mechanisms to plausibility probes across different issue-areas (Eckstein 1975). As an intermediate step between hypothesis generation and hypothesis testing, plausibility probes serve an important function in theory development (Levy 2008: 7).

Our universe of cases consists of all instances in which institutional overlap is deliberately created by establishing a new international institution. Out of this universe we select three cases for empirical investigation that vary on our central explanatory variable: type of dissatisfaction with the institutional status quo. That is, each of our three cases features one specific type of dissatisfaction: dissatisfaction with substantive norms and/or rules (IEA/IRENA case), dissatisfaction with decision-making rules (WB/AIIB case) and dissatisfaction with institutional fit (GEF case). This case selection technique enables us to investigate whether our theoretical propositions on how the consequences of deliberately created institutional overlap are related to its causes are borne out empirically (cf. King et al. 1994: 137-41).

\section{Institutional overlap between IEA and IRENA}

IRENA was created because a group of states was dissatisfied with the substantive focus of the IEA on fossil fuels as the main energy sources and 
the corresponding norms it promoted. ${ }^{6}$ IRENA's creation was driven by the desire to shape new substantive norms that promote renewable energies in order to 'offset the IEA's perceived bias in favor of the fossil fuel and nuclear industries' (Van de Graaf and Lesage 2009: 301). Its creation led to interface conflicts between the supporters of both institutions.

Dissatisfaction with the substantive norms promoted by the IEA. The primary governance objective of the IEA is to 'promote secure oil supplies on reasonable and equitable terms' (IEP Agreement 1974: 5). Despite the broadening of IEA's scope by the adoption of the Shared Goals (energy security, economic development and environmental protection) (IEA 1993), a group of states led by Germany perceived that its work continued to favour fossil fuels and nuclear energies. The IEA was accused of institutional blindness, inter alia because it upheld implementation agreements advancing research on nuclear energies instead of accommodating states' growing demands for renewable energies (Adam 2009). Hermann Scheer, a leading figure in the creation of IRENA, vividly articulated this position by claiming that the IEA 'leaves no stone unturned when it comes to emphasizing the long-term indispensability of nuclear and fossil energy' (Scheer 2007: 174). As concerns over climate change grew, this group of states increasingly saw renewable energies as viable alternatives to the conventional energy sources still promoted by the IEA. However, the IEA proved to be 'structurally frozen in time' (Colgan et al. 2012: 126). Its analyses continued to underestimate 'the potential of renewable sources of energy' (Van de Graaf 2013a: 26) and to promote oil, coal and nuclear energy as 'irreplaceable' energy sources (Van de Graaf and Lesage 2009: 309). In 2009, it spent only 2 per cent of its total budget on renewables. ${ }^{7}$ As a result, the IEA was accused of obstructing a global shift to renewable energies (Van de Graaf 2013b: 96).

Policy-motivated institutional creation of IRENA. Seeing major changes in IEA policies to accommodate renewable energies as highly unlikely, the dissatisfied states created a new institution: IRENA. Its purpose is to 'promote the widespread and increased adoption and the sustainable use of all forms of renewable energy' (Article II IRENA Statute). To that end, IRENA provides policy advice, gathers and disseminates information, and engages

\footnotetext{
${ }^{6}$ The IEA lacks 'directive influence over the energy policy decisions of its member countries' (Heubaum and Biermann 2015: 236). It does, however, advocate certain courses of action by gathering and interpreting information, by providing recommendations and advice for its members and by facilitating technology transfer. In doing so, it spreads substantive norms.

7 <https://www.renewableenergyworld.com/articles/2009/06/interview-hans-jrgen-kochexplains-why-irena-is-50-times-more-than-the-iea.html>.
} 
in capacity building, the promotion of technology transfer and the stimulation of research (Colgan et al. 2012: 129).

IRENA 'was promoted explicitly as a counterweight to, and remedy for the failings of, the [IEA]' (Overland and Reischl 2018: 337). That is, it was created to 'counter the IEA's alleged supportive stance toward the fossil and nuclear energy industries' (Van de Graaf 2013b: 108). Hans Jørgen Koch, a member of the Danish parliament's energy and climate committee, asserts 'For ten years the IEA has underestimated the competitiveness of renewable energy sources (...) so there is a clear need for IRENA' (Young 2009: 2). Thus, the motivation to create IRENA was to incite policy change by redirecting the focus of global energy governance from fossil fuels to renewable energies. It therefore comes as no surprise that prominent members of the IEA (the United States (US), France, Great Britain, Canada, Japan, Australia and Italy) were opposed to IRENA (Van de Graaf 2013b: Ch 5).

The effects of policy-motivated institutional overlap: Interface conflict on energy security and mitigating climate change. The promotion of renewable energies through IRENA directly challenges the IEA's substantive focus on fossil fuel and nuclear based energy systems. Moreover, the IEA's core principles of centralised energy security directed at industrialised states starkly contrast with IRENA's principles of voluntariness and decentralised renewable energy provision directed at industrialising states (Dubash and Florini 2011).

A central issue in which states perceive great difficulty to reconcile the objectives of IEA and IRENA is the provision of global energy security and the mitigation of climate change. In a highly fragmented global energy system, energy supply security and environmental sustainability cannot be attained to the same degree simultaneously. Thus, positional differences on how to balance these two governance objectives emerged between major industrialised and industrialising states (Dubash and Florini 2011).

A variety of speech acts by the proponents of the IEA and those of IRENA shows that an interface conflict exists with regard to the prevalence of substantive global energy supply norms promoted by both institutions. Major industrialised states continue to recognise the IEA as an authority in the field of global energy security. For example, the US and Australia openly advocate for ensuring energy security through the use of coal resources. They further argue that coal resources 'offer opportunity for developing nations to access tomorrow's coal technology to improve energy security' (Watts 2018). In 2015, Australian energy minister Josh Frydenberg presented a 'moral case' in which he portrays the IEA as an authority to strengthen Australia's position that coal is a reliable future energy source. Frydenberg claims that ' $[t]$ here's a clear increase in demand 
for coal and indeed energy across the world [...] and the International Energy Agency says $75 \%$ of [energy] demand [in 2040] will be met by fossil fuels' (Milman 2015).

In contrast, major industrialising states, especially China, perceive the IEA to continually favour coal power plants despite their undeniable contribution to anthropogenic climate change. Thus, they support the substantive norms promoted by IRENA. For example, China utilises IRENA's principle to support economic development and contends that industrialising states 'should be afforded some leniency in emissions as they are currently in critical stages of economic development' (Council on Foreign Relations 2013).

Given that major industrialised and industrialising states have incompatible positions on energy security and the mitigation of climate change, they cannot reach an agreement on the scope and applicability of the substantive norms promoted by IEA and IRENA. Hence, the interface conflict persists. As the Introduction to this Special Issue suggests, there is, however, the possibility that it incites coordination in the long run. The 'greening' of the IEA and its efforts to establish a partnership with IRENA indicate that actors within both institutions are interested in developing a coordinated response (Heubaum and Biermann 2015). However, these efforts have hitherto not resolved the persistent positional differences between major industrialised and industrialising countries. Irrespective of whether this will happen in the future, key for our article is that an interface conflict emerged at all in this case.

\section{Institutional overlap between the AIIB and the World Bank}

Rising powers create institutional overlap because established powers are hesitant to redistribute influence within existing international institutions in ways that acknowledge their increased power resources (Ikenberry and Lim 2017). China's creation of the AIIB is a case in point. Since the US did not agree to expand China's institutional power within the WB in accordance with its overall economic power, China launched the AIIB (Pratt 2017).

China's dissatisfaction with the decision-making rules of the World Bank. Starting in 2010, China vehemently voiced discontent that its increase in economic power and in its financial contribution to the WB did not translate into greater WB vote shares. ${ }^{8}$ Chinese Finance Minister Xie Xuren demands that ' $[t]$ he future shareholding principles should continue to be based on

$8<$ http://www.worldbank.org/en/country/china/overview>. 
economic weight, $[\ldots]$ and aim to achieve the ultimate goal of equitable voting power between developing countries and developed countries' (Xinhua 2010).

At several occasions, the sense of unfairness with existing decisionmaking procedures was articulated publicly: At the WB and the International Monetary Fund's (IMF) Annual Meeting in Lima in 2015, Chinese Finance Minister Jiwei Lou urged the WB 'to continuously push forward governance reform and notably increase the voice and representation of developing countries [...] based on the changing global economic weight, so that the developing world can play a greater role in the Bank's decision making process' (Lou 2015). Moreover, at the World Economic Forum 2017, Chinese President Xi Jinping said that '[e]merging markets and developing countries deserve greater representation and voice' in the US-dominated development banks (Jinping 2017).

However, China's efforts to redistribute influence in the WB were unsuccessful. To be sure, the WB underwent a 'voice reform' to increase the voting powers of developing states in 2016, but minuscule changes in the WB's decision-making rules were not even close to satisfying China's longing for more equitable vote distribution (Vestergaard and Wade 2015: 6).

The power-based motivation to create the AIIB. Because of the persistence of its low influence on collective decision-making within the WB, China launched the AIIB. To be sure, China also criticised the WB for its failure to provide financial assistance when the global economy was in crisis. Moreover, it justifies the creation of the AIIB with regard to strengthening the global economy and its capacities for regional infrastructure development. However, its main motivation for creating the AIIB was to increase its influence on collective decision-making (Hashmi 2015). China possesses 26.64 per cent of the vote shares in the AIIB, which contrasts with the 4.45 per cent of the vote shares it holds in the WB. ${ }^{9}$

Inter-institutional coordination between the AIIB and the WB. Although the US initially sought to limit the AIIB membership, this initial strife did not lead to an interface conflict between the US and China. Rather, the creation of the AIIB led to inter-institutional coordination developed and recognised by the proponents of both institutions.

Inter-institutional coordination manifests itself in different ways. First, the AIIB mandate closely resembles the structure and content of the WB mandate. This is unsurprising because the AIIB used the WB mandate as a

\footnotetext{
9 <https://www.aiib.org/en/about-aiib/governance/members-of-bank/index.html>.
} 
template for its own regulatory framework (Lichtenstein 2018). ${ }^{10}$ As a result, the substantive norms and rules enshrined in the two development banks do not differ. The occurrence of an interface conflict is therefore unlikely to begin with.

Second, and relatedly, the governance objectives of the WB and the AIIB closely align. In essence, the AIIB joins WB efforts to 'foster economic growth in the developing world' (Liao 2015). Instead of handling this overlap as a rivalry, China repeatedly encourages cooperation among the banks and reaffirms that the AIIB poses no threat to any other development bank. In Chinese Foreign Minister Hong Lei's words, the 'AIIB will complement existing multilateral development banks' (Xinhua 2015). To date, two-thirds of all AIIB projects are co-financed (Gutner 2018).

China's continued recognition of the WB as an authority in development banking is further reciprocated by the US. In 2015 US President Barack Obama backtracked on earlier US hostilities toward the AIIB by saying 'let me be very clear and dispel this notion that we were opposed or are opposed to other countries participating in the [AIIB....We] look forward to collaborating with the [AIIB], just like we do with the [Asian Development Bank] and with the [WB]' (Obama 2015).

Third, inter-institutional coordination between the AIIB and the WB is institutionalised in Memoranda of Understanding. More precisely, the AIIB and the WB have developed collaborative arrangements to be able to co-finance projects efficiently. Alone in 2016, the same year that the AIIB became operational, collaborative arrangements supported five co-financed projects in Pakistan, Azerbaijan and Indonesia (World Bank 2017). Within these arrangements, the AIIB and WB agreed on joint supervision during project implementation with the WB being the lead supervisor (e.g. AIIB 2016). The AIIB, for its part, regards the WB loan conditions as 'satisfactory' (AIIB 2017) and even 'rel[ies] on the WB's determination of compliance with the [...] WB policies and procedures' (AIIB 2016: 5). Thus, both development banks effectively ensure environmental and social standards as part of project implementations. In sum, the deliberate creation of institutional overlap resulted in inter-institutional coordination between the AIIB and the WB.

\section{Institutional overlap between the UNFCCC, the WB and the GEF}

The GEF was created to enable financial transfers from developed to developing countries and countries with economies in transition. These

10 The AIIB mandate was established under the guidance of Natalie Lichtenstein, a former senior official at the WB. China's decision to bestow the role of Chief Counsel in the AIIB's founding process upon her signifies a strategic move by China to avoid interface conflicts. 
transfers were supposed to provide the latter countries with the resources needed to meet the commitments they enter(ed) into under various (existing and newly emerging) international environmental agreements. More precisely, the GEF was created to play a functional role in supporting environmental projects conducted under the umbrella of the UN Framework Convention on Climate Change (UNFCCC), the UN Development Programme (UNDP), the UN Environmental Programme (UNEP) and the World Bank. To that effect, it was designed to complement the governance activities of existing (and newly emerging) institutions.

The dissatisfaction of industrialised states with institutional fit. At the World Bank-IMF Meeting in 1989, France questioned the WB's ability to finance global environmental projects and proposed the creation of a global environment fund. On behalf of the Member States of the European Communities, Pierre Bérégovoy, French Minister of Economy and Finance, proclaimed that ' $[\mathrm{e}] \mathrm{ach}$ country must mobilise its own resources, but France believes that the World Bank must also be provided with specific additional resources so that it can encourage large-scale programs' (Bérégovoy 1989: 79).

The demand of major industrialised states for additional resources to finance environmental projects arose from their dissatisfaction with the insufficient ability of existing institutions to redistribute financial resources from developed to developing countries in order to effectively protect the environment. In other words, those states considered existing institutions unable to fulfil a governance function that is indispensable for effective global environmental governance.

In his address to Congress in 1992, US President George H. W. Bush envisioned that the GEF would 'become the principal vehicle for assisting developing nations with the incremental costs of gaining global environmental benefits under new international agreements' (Bush 1992). President Bush succinctly summarises the position that the WB and UN environmental as well as developmental capacities do not suffice to find appropriate solutions to environmental problems. Thus, the creation of a new institution was considered necessary to effectively protect the environment by redistributing financial resources from developed to developing countries (ODI 1993).

Effectiveness-motivated overlap to establish a mechanism for financing global environmental projects. The then WB President Barber Conable explicitly pointed to the potential of a separate fund for financing environmental projects to enhance governance effectiveness: 'It appears that there is broad agreement on the notion of providing additional concessional 
resources to support environmental actions with global implications, where the current funding arrangements do not provide borrowing countries with sufficient incentive to do so' (Conable 1990, emphasis added).

The GEF was first launched in November 1990 as a three-year pilot project. Over time, it 'emerged as the major international mechanism for funding global environmental efforts' (ODI 1993: 3). Among other things, it invests in projects that target the reduction of carbon emissions, sustainable landscapes and seascapes, water resource management, safe disposal of hazardous chemicals and protected areas.

Inter-institutional coordination between GEF, other international environmental institutions and the WB. The GEF was from the outset designed to complement the governance activities of other international institutions. The WB resolution for creating the GEF entails a tripartite agreement stipulating that UNEP heads the strategic planning of the GEF to ensure that its operations are in alignment with the objectives of international environmental agreements. UNDP organises studies and assessments to support GEF operations, and the WB administers the GEF's core TrustFund and manages the project cycle for global environmental investments (World Bank 1991).

Inter-institutional coordination is further strengthened through a Memorandum of Understanding which was established between the UNFCCC and the WB. As a result, the UNFCCC Executive Secretaries repeatedly praised their 'strong collaboration' (Figueres 2011) and reassured the 'full commitment of the Climate Change secretariat to build stronger collaboration with the GEF as part of our joint pursuit of supporting Parties in achieving the objective of the Convention' (de Boer 2010, emphasis added). Moreover, the GEF financing of the CC:TRAIN project to educate and assist civil servants in implementing UNFCCC objectives, as well as GEF financing of UNFCCC-related country studies on its climate objectives and inventories of emitted greenhouse gases such as in the Maldives and Tunisia contribute to inter-institutional coordination (Young and Boehmer-Christiansen 1998).

Major industrialised countries such as Australia and Canada recognise the authority of the GEF in global environmental governance. In its Multilateral Assessment report, Australia recognises GEF's strong complementarity to the existent governance system as 'GEF effectively coordinates the international response to these conventions and, thereby, plays an important role' (Australian Government 2012: 5). Australia perceives that GEF values not only align with environmental structures, but also with partner country priorities (Australian Government 2012: 11). In a similar manner, Canada notes the GEF's careful adaptation to the existing multilateral 
system: 'By supporting the GEF, Canada helps developing countries implement their multilateral environmental agreements' (Government of Canada 2019). Interface conflicts, by contrast, are not observable.

Since the GEF gets a mandate from other international institutions, one may argue that the emergence of interface conflicts is prevented by institutional design. Its inherent plausibility notwithstanding, such an objection sits uneasily with the conventional wisdom that deliberately created institutional overlap is particularly conflict-ridden. The broader contribution of this case study is therefore to exemplify that an exclusive analytical focus on norm collisions and interface conflicts risks overlooking other phenomena that are equally relevant for understanding international legal multiplicity (Dunoff 2012).

\section{Conclusion}

Existing research suggests that deliberately created institutional overlap virtually always leads to conflicts between groups of actors that support diverging norms and rules (Benvenisti and Downs 2007; Morse and Keohane 2014). We, in contrast, demonstrate that this particular type of overlap can also lead to inter-institutional coordination. More precisely, we demonstrate that the consequences of deliberately created institutional overlap depend on why exactly states are dissatisfied with the institutional status quo. Interface conflicts emerge only if states are dissatisfied with the substantive norms and/or rules of an existing institutional arrangement and, thus, seek to induce policy change. In contrast, if states are dissatisfied with decision-making rules, the creation of institutional overlap gives rise to inter-institutional coordination. Likewise, if states are dissatisfied with the institutional fit of an existing governance arrangement and seek to enhance governance effectiveness, institutional overlap results in inter-institutional coordination. These findings suggest that interface conflicts are less widespread than commonly expected (cf. Kreuder-Sonnen and Zürn, this issue).

Each of our three empirical cases represents a much larger universe of cases which revolves around a specific type of dissatisfaction with the institutional status quo. The universe revolving around dissatisfaction with substantive norms and/or rules accommodates, among others, the attempt of developed countries to induce policy change in the international protection of intellectual property rights by adopting the WTO TRIPS Agreement, the creation of the Shanghai Cooperation Organization and the creation of the Proliferation Security Initiative. In all three cases, interface conflicts emerged between the proponents of the newly created institutions and those defending the incumbent ones, namely the World Intellectual Property 
Organization, the UN and the Organization for Security and Cooperation in Europe, and the UN Convention on the Law of the Sea.

The universe of cases revolving around dissatisfaction with decisionmaking rules is particularly relevant against the backdrop of the current shift in the global power distribution. It includes various instances of overlap between the time-tested institutions created by established powers and other institutions recently established by rising powers, for example the New Development Bank. As long as rising powers are primarily dissatisfied with the decision-making rules of incumbent institutions, the occurrence of interface conflicts between rising and established powers is unlikely.

Finally, the universe of cases revolving around dissatisfaction with institutional fit includes, for example, the creation of the Financial Stability Forum which the G-7 states created in response to the 2008 financial crisis in order to rectify the deficiencies of the existing institutions (Clarke 2014). In sum, it is safe to say that our three empirical cases belong to larger populations which can be analysed by the causal mechanisms developed in this article.

Our findings support previous research on global legal pluralism which points to the potential of international legal multiplicity to give rise to coherent and flexible global governance (Krisch 2010). By implication, they call into doubt the position of those global constitutionalists who argue that the coexistence of partially overlapping normative orders is inherently destabilising the international legal system (Dunoff and Trachtman 2009; Wiener et al. 2012).

\section{Acknowledgements}

This article was created as part of the research project Overlapping Spheres of Authority and Interface Conflicts in the Global Order (OSAIC). We thank the German research foundation (DFG) for their funding. We also thank all commentators for their valuable feedback on earlier versions of this article presented at the ECPR conference (August 2018), the DVPW Congress (September 2018) and the ISA conference (March 2019). We are particularly indebted to Kenneth W. Abbott and Philipp Genschel.

\section{References}

Adam, David. 2009. "International Energy Agency.” The Guardian available at: <https://www. theguardian.com/environment/2009/jan/08/windpower-energy>.

AIIB. 2016. Project Document of AIIB. Islamic Republic of Pakistan, Tarbela 5 Hydropower Extension Project. Asian Infrastructure Investment Bank (9 December) available at: <https://www.aiib.org/en/projects/approved/2016/_download/pakistan-tarbela-5/ approved_project_document_tarbela_5_hydropower_extension.pdf >. 
AIIB. 2017. Project Document of AIIB. Regional Infrastructure Development Fund Project, Republic of Indonesia. Asian Infrastructure Investment Bank (27 March) available at: <https://www.aiib.org/en/projects/approved/2017/_download/indonesia/document/ project-document_Indonesia_Regional_Infrastructure_Development_Fund.pdf>.

Alter, Karen J. and Kal Raustiala. 2018. “The Rise of International Regime Complexity.” UCLA School of Law, Public Law Research Paper No. 17-47.

Australian Government. 2012. "Australian Multilateral Assessment. Global Environment Facility (GEF)." Canberra, Australia.

Benvenisti, Eyal and George W. Downs. 2007. “The Empire’s New Clothes: Political Economy and the Fragmentation of International Law." Stanford Law Review 60(2):595-632.

Bérégovoy, Pierre. 1989. "1989 Annual Meetings of the Boards of Governors: Summary Proceedings.” Report No. 53426:75-84. Washington D.C.: World Bank Group.

Bush, George H.W. 1992. "Message to the Congress on Environmental Goals." (24 March) available at: <https://www.presidency.ucsb.edu/documents/message-the-congress-envi ronmental-goals $>$.

Clarke, Warren. 2014. "Creating the Financial Stability Forum: What Role for Existing Institutions?" Global Society 28(2):196-216.

Clarke, Warren. 2019. "Institutional Density Reconsidered: States, International Organisations, and the Governance Space.” Journal of International Relations and Development 22(3): 698-721.

Colgan, Jeff D., Robert O. Keohane and Thijs Van de Graaf. 2012. "Punctuated Equilibrium in the Energy Regime Complex." Review of International Organizations 7(2):117-43.

Conable, Barber B. 1990. "Draft Letter to invite Ministers on holding a Meeting on Environmental Funding, as presented to the Senior Vice President of Operations, Moeen A. Qureshi." (24 January). The World Bank Group Archives.

Council on Foreign Relations. 2013. "The Global Climate Change Regime." available at: $<$ https://www.cfr.org/report/global-climate-change-regime>.

De Boer, Yvo. 2010. "Statement by Yvo de Boer, Executive Secretary, United Nations Framework Convention on Climate Change.” Fourth GEF General Assembly. Punta del Este, Uruguay.

De Búrca, Gráinne. 2016. “Contested or Competitive Multilateralism? A Reply to Julia C. Morse and Robert O. Keohane." Global Constitutionalism 5(3):320-6.

Dubash, Navroz K. and Ann Florini. 2011. "Mapping Global Energy Governance." Global Policy 2(s1):6-18.

Dunoff, Jeffrey L. 2012. “A New Approach to Regime Interaction.” In Regime Interaction in International Law: Facing Fragmentation, edited by Margaret A. Young, 136-74. Cambridge: Cambridge University Press.

Dunoff, Jeffrey L. and Trachtman, Joel P. 2009. Ruling the World? Constitutionalism, International Law, and Global Governance. Cambridge: Cambridge University Press.

Eckstein, Harry. 1975. "Case Study and Theory in Political Science." In Handbook of Political Science (7th edn), edited by Fred I. Greenstein and Nelson W. Polsby, 79-138. Reading, MA: Addison-Wesley.

Figueres, Christiana. 2011. "Statement by Christiana Figueres, Executive Secretary, United Nations Framework Convention on Climate Change." GEF Council Meeting 24-26 May 2011. Washington D.C.

Gehring, Thomas and Benjamin Faude. 2013. "The Dynamics of Regime Complexes: Microfoundations and Systemic Effects." Global Governance 19(1):119-30.

Gehring, Thomas and Benjamin Faude. 2014. "A Theory of Emerging Order within Institutional Complexes: How Competition among Regulatory International Institutions leads to Institutional Adaptation and Division of Labor." The Review of International Organizations 9(4):471-98. 
Government of Canada. 2019. "Project Profile - Sixth Replenishment (2014-2018) - Global Environment Facility (GEF) - II.” (13 February) available at: <http://w05.international. gc.ca/projectbrowser-banqueprojets/project-projet/details/D000166002>.

Gutner, Tamar. 2018. “AIIB: Is the Chinese-led Development Bank a Role Model?” Council on Foreign Relations (25 June) available at: <https://www.cfr.org/blog/aiib-chinese-led-devel opment-bank-role-model>.

Hashmi, Shabir. 2015. "The Genesis of AIIB and the Role of China in Promoting the Global Economy." China Daily (12 March) available at: <http://www.chinadaily.com. cn/opinion/2015-05/12/content_20692641.htm>.

Helfer, Laurence R. 2009. "Regime Shifting in the International Intellectual Property System." Perspectives on Politics 7(1):39-44.

Heubaum, Harald and Frank Biermann. 2015. "Integrating Global Energy and Climate Governance: The Changing Role of the International Energy Agency.” Energy Policy 87(C): 229-39.

Hofmann, Stéphanie C. 2011. "Why Institutional Overlap Matters: CSDP in the European Security Architecture." Journal of Common Market Studies 49(1):101-20.

IEA. 1993. "IEA Shared Goals.” International Energy Agency (4 June) available at: <https:// www.iea.org/about/history>.

IEP Agreement. 1974. “Agreement on an International Energy Program.” International Energy Agency available at: $<$ https://www.iea.org/about/history>.

Ikenberry, John G. and Darren J Lim. 2017. “China's Emerging Institutional Statecraft: The Asian Infrastructure Investment Bank and the Prospects of Counter-Hegemony.” Project on International Order and Strategy. Washington D.C.: Brookings Institute.

ILC. 2006. "Fragmentation of International Law: Difficulties Arising from the Diversification and Expansion of International Law." International Law Commission (July 18). UN General Assembly Report A/CN.4/L.702.

Jinping, Xi. 2017. "Full Text of Xi Jinping Keynote at the World Economic Forum.” available at: $<$ https://america.cgtn.com/2017/01/17/full-text-of-xi-jinping-keynote-at-the-world-eco nomic-forum>.

Keohane, Robert O. 1988. “International Institutions: Two Approaches.” International Studies Quarterly 32(4):379-96.

King, Gary, Robert O. Keohane and Sidney Verba. 1994. Designing Social Inquiry: Scientific Inference in Qualitative Research. Princeton, NJ: Princeton University Press.

Koremenos, Barbara, Charles H. Lipson and Duncan Snidal. 2001. "The Rational Design of International Institutions.” International Organization 55(4):761-99.

Koskenniemi, Martti. 2012. “Hegemonic Regimes.” In Regime Interaction in International Law: Facing Fragmentation, edited by Margaret A. Young, 305-24. Cambridge: Cambridge University Press.

Krasner, Stephen D. 1991. "Global Communications and National Power: Life on the Pareto Frontier." World Politics 43(3):336-66.

Kreuder-Sonnen, Christian and Michael Zürn. 2020. "After Fragmentation: Norm Collisions, Interface Conflict, and Conflict Management.” Global Constitutionalism 9(2):241-267

Krisch, Nico, Francesco Corradini and Lucy Lu Reimers. 2020. "Order at the Margins: The Legal Construction of Norm Collisions over Time.” Global Constitutionalism 9(2):343-363.

Krisch, Nico. 2010. Beyond Constitutionalism: The Pluralist Structure of Postnational Law. Oxford: Oxford University Press.

Lang Jr., Anthony F., Mattias Kumm, Antje Wiener, James Tully and Miguel Poiares Maduro. 2013. "Interdisciplinarity: Challenges and Opportunities." Global Constitutionalism 2 (1):1-5. 
Levy, Jack S. 2008. “Case Studies: Types, Designs, and Logics of Inference.” Conflict Management and Peace Science 25(1):1-18.

Liao, Rebecca. 2015. "Out of the Bretton Woods: How the AIIB Is Different.” Foreign Affairs available at: <https://www.foreignaffairs.com/articles/asia/2015-07-27/out-bretton-woods>.

Lichtenstein, Natalie. 2018. A Comparative Guide to the Asian Infrastructure Investment Bank. Oxford: Oxford University Press.

Lou, Jiwei. 2015. “Statement by Hon. Jiwei Lou, Governor of the Bank for the People's Republic of China.” World Bank Group (9 October) available at: <https:/www.imf.org/external/ am/2015/speeches/pr29e.pdf>.

Mayntz, Renate. 2009. "Soziale Mechanismen in der Erklärung gesellschaftlicher Makrophänomene." In Sozialwissenschaftliches Erklären. Probleme der Theoriebildung und Methodologie, edited by Renate Mayntz, 97-122. Frankfurt and New York, NY: Campus.

Milman, Oliver. 2015. "Josh Frydenberg Puts 'Strong Moral Case' for Coal Exports to Prevent Deaths." The Guardian available at: <https://www.theguardian.com/australia-news/2015/ oct/18/josh-frydenberg-puts-strong-moral-case-for-coal-exports-to-prevent-deaths>.

Morse, Julia C. and Robert O Keohane. 2014. "Contested Multilateralism." The Review of International Organizations 9(4):385-412.

Obama, Barack. 2015. "Remarks by President Obama and Prime Minister Abe of Japan in Joint Press Conference.” (28 April) available at: <https://obamawhitehouse.archives.gov/thepress-office/2015/04/28/remarks-president-obama-and-prime-minister-abe-japan-jointpress-confere $>$.

ODI. 1993. “The Global Environment Facility: What's In It for Developing Countries? ” Briefing Paper. London: Overseas Development Institute. https://www.odi.org/publications/5474global-environment-facility-whats-it-developing-countries.

Overland, Indra and Gunilla Reischl. 2018. "A Place in the Sun? IRENA's Position in the Global Energy Governance Landscape.” International Environmental Agreements: Politics, Law and Economics 18(3):335-50.

Pratt, Tyler. 2017. “Angling for Influence: Institutional Proliferation in Development Banking.” Working Paper available at: <https://scholar.princeton.edu/sites/default/files/tylerpratt/ files/influence_aug25.pdf>.

Scheer, Hermann. 2007. Energy Autonomy: The Economic, Social and Technological Case for Renewable Energy. London: Earthscan.

Schelling, Thomas. 1998. "Social Mechanisms and Social Dynamics." In Social Mechanisms: An Analytical Approach to Social Theory, edited by Peter Hedström and Richard Swedberg, 32-44. Cambridge: Cambridge University Press.

Van de Graaf, Thijs. 2013a. "Fragmentation in Global Energy Governance: Explaining the Creation of IRENA." Global Environmental Politics 13(3):14-33.

Van de Graaf, Thijs. 2013b. The Politics and Institutions of Global Energy Governance. Basingstoke: Palgrave Macmillan.

Van de Graaf, Thijs and Dries Lesage. 2009. "The International Energy Agency after 35 Years: Reform Needs and Institutional Adaptability." Review of International Organizations 4 (3):293-317.

Vestergaard, Jakob and Robert H Wade. 2015. "Still in the Woods: Gridlock in the IMF and the World Bank Puts Multilateralism at Risk." Global Policy 6(1):1-12.

Watts, Jonathan. 2018. "Protesters Disrupt US Panel's Fossil Fuels Pitch at Climate Talks.” The Guardian (10 December) available at: <https://www.theguardian.com/environment/ 2018/dec/10/protesters-disrupt-us-panels-fossil-fuels-pitch-at-climate-talks>. 
Wiener, Antje, Anthony F. Lang Jr., James Tully, Miguel Poiares Maduro and Mattias Kumm. 2012. "Global Constitutionalism: Human Rights, Democracy and the Rule of Law. Global Constitutionalism 1(1):1-15.

World Bank. 1991. Resolution No.91-95. Global Environment Facility.

World Bank. 2017. "World Bank and AIIB Sign Cooperation Framework." (April 23) available at: <http://www.worldbank.org/en/news/press-release/2017/04/23/world-bank-and-aiibsign-cooperation-framework>.

Xinhua. 2010. "China's Influence Grows at World Bank.” China Daily (26 April) available at: <http://www.chinadaily.com.cn/china/2010-04/26/content_9772218.htm>.

Xinhua. 2015. “AIIB, a Case for Cooperation.” China Daily (14 March) available at: <http:// www.chinadaily.com.cn/business/2015-03/14/content_19811308.htm>.

Young, Oran R. 2002. The Institutional Dimensions of Environmental Change: Fit, Interplay, and Scale. Cambridge, MA: MIT Press.

Young, Tom. 2009. "International Renewable Energy Agency Launches Today.” BusinessGreen available at: <https:/www.businessgreen.com/bg/news/1803825/international-renewableenergy-agency-launches>.

Young, Zoe and Sonja Boehmer-Christiansen. 1998. "Green Energy Facilitated? The Uncertain Function of the Global Environment Facility." Energy and Environment 9(1):1-28.

Zelli, Fariborz and Harro van Asselt. 2013. "Introduction: The Institutional Fragmentation of Global Environmental Governance: Causes, Consequences, and Responses.” Global Environmental Politics 13(3):1-13.

Zürn, Michael and Benjamin Faude. 2013. "Commentary: On Fragmentation, Differentiation, and Coordination." Global Environmental Politics 13(3):119-30. 